\title{
Pengaruh Status Sosial Ekonomi Keluarga dan Teman Sebaya Terhadap Minat Melanjutkan Pendidikan Ke Tingkat SLTA di MTs se Kecamatan Kwanyar
}

\author{
Moh.Rowi \\ Program Studi S1 Pendidikan Ekonomi, Fakultas Ekonomi, Universitas Negeri Surabaya \\ Email: moh.rowi@mhs.unesa.ac.id \\ Yoyok Soesatyo \\ Program Studi S1 Pendidikan Ekonomi, Fakultas Ekonomi, Univeritas Negeri Surabaya \\ Email: yoyoksoesatyo@unesa.ac.id
}

\begin{abstract}
ABSTRAK
Tujuan penelitian ini untuk menganalisis pengaruh status sosial ekonomi keluarga terhadap minat melanjutkan pendidikan ke tingkat SLTA, pengaruh teman sebaya terhadap minat melanjutkan pendidikan ke tingkat SLTA serta pengaruh status sosial ekonomi keluarga dan teman sebaya terhadap minat melanjutkan pendidikan ke tingkat SLTA di MTs se Kecamatan Kwanyar. Metode penelitian ini menggunakan pendekatan kuantitatif kausal dengan jumlah populasi sebanyak 113 dan sampel sebanyak 88 yang diambil dengan menggunakan teknik random sampling. Analisis yang digunakan adalah analisis Regresi linier berganda. Berdasarkan hasil penelitian, (1) Terdapat pengaruh yang signifikan antara status sosial ekonomi keluarga terhadap minat melanjutkan pendidikan di tingkat SLTA, (2) Tidak terdapat pengaruh yang signifikan antara teman sebaya terhadap minat melanjutkan pendidikan di tingkat SLTA, (3) Terdapat pengaruh antara status sosial ekonomi keluarga dan teman sebaya terhadap minat melanjutkan pendidikan ke tingkat SLTA di MTs se Kecamatan Kwanyar.
\end{abstract}

Kata Kunci: Status Sosial Ekonomi Keluarga, Teman Sebaya, Minat Melanjutkan Tingkat SLTA.

\section{ABSTRACT}

The purpose of this research to analyze the effect of socio-economic status of the family towards the interest in continuing education to the senior high school level, the effect of peers towards the interest in continuing education to the senior high school level and the effect of socio-economic status of family and peers towards the interest in continuing education to the senior high school education at Madrasah Tsanawiyah in Kwanyar District. This research method uses a quantitative causal which is used the number of 113 populations and 88 samples which is taken using the random sampling technique. The analysis used is the analysis of multiple linear regression. Based on the results of the research, (1) There is a significant influence between socio-economic status of the family towards the interest in continuing education in the senior high school level, (2) There is no significant influence between peers towards the interest in continuing education to the senior high shool level, (3) There is a significant between socio-economic status of the family and peers towards the interest in continuing education in the senior high school level at Madrasah Tsanawiyah in Kwanyar District

Keywords: Social Status Economy Family, peerfriend, Interest to Continue Senior High Schooll. 


\section{PENDAHULUAN}

Salah satu kebutuhan yang paling utama dalam kehidupan manusia yaitu butuhnya seseorang akan pendidikan, karena pendidikan merupakan sebuah tahapan atau proses seseorang untuk menambah sebuah pengalaman atau wawasan yang dapat membantu seseorang untuk melawan tantangan dimasa yang akan datang. Pendidikan yang paling utama yaitu pendidikan yang diberikan oleh keluarga baik orang tua sendiri maupun saudara-saudara dan orang disekitarnya. Banyak sekali macam pendidikan yang bisa menjadi pilihan bagi seseorang untuk mengembangkan potensinya.

Menurut Ihsan, (2008)Pendidikan adalahsebuah usaha yang dikerjakan oleh manusia yang tujuannya untuk menumbuhkan dan mengembangkan potensinya baik yang berupa jasmani maupun yang berupa rohani yang sesuai dengan nilai-nilai yang berada dilingkungan sekitar.

Alur dalam pendidikan dibedakan menjadi 3 bagian yaitu: (1) pendidikan formal, (2) Pendidikan non formal dan (3) Pendidikan informal. Pendidikan formal yaitu pendidikan yang diperoleh melalui lembaga pendidikan yang berjenjang mulai dari yang paling rendah sampai yang paling tinggi, seperti pendidikan dasar, pendidikan menengah pertama dan pendidikan menengah atas. Pendidikan nonformal yaitu jalur pendidikan yang dilakukan diluar pendidikan formal yang bisa dilaksanakan secara terstruktur serta berjenjang, pendidikan ini biasanya dilakukan pada anak-anak yang berusia dini seperti PAUD,TK,TPAAndrienzens, ( 2008).

Selain itu pendidikan nonformal lainnya seperti kursus baik kursus musik maupun kursus yang lainnya.Adapun fungsi dengan adanya pendidikan nonformal yaitu untuk meningkatkan kemampuan siswa yang lebih memfokuskan terhadap penguasaan pengetahuan dan keterampilan fungsional serta meningkatkan sikap dan kepribadian yang profesional.Selanjutnya pendidikan informal yaitu jalur pendidikan yang terjadi dikeluarga dan lingkungan sekitar yang dilakukan secara sadar dan bertanggung jawab atas segala yang terjadi didalamnya.Dalam pendidikan informal ini tidak harus belajar didalam sebuah ruangan, artinya yaitu bebas mau dimana saja pelaksanaanya serta tidak ada jenjang dan juga persyaratan khusus untuk masuk atau tergabung kedalam pendidikan tersebut.

Didalam sebuah pendidikan sarana dan prasarana sangat penting dan sangat dibutuhkan, karena sarana dan prasarana tersebut dapat membantu proses penyelenggara belajar serta mengajar, baik mengajar secara langsung ataupun secara tidak langsung. Jika didalam sebuah instansi khususnya yang berbasis pendidikan formal salah satu dari sarana dan prasarananya kurang, maka proses pendidikan itu tidak akan berjalan secara lancar dan maksimal.

Selain sarana dan prasarana hal yang dibutuhkan dalam pendidikan yaitu dorongan serta dukungan dari orang tua, karena jika seseorang yang sedang mengecam pendidikan tanpa adanya dorongan dan dukungan dari orang tua atau keluarga maka ibaratkan ibaratkan orang yang berjalan dengan menggunakan hanya dengan satu kaki, artinya orang tersebut tidak maksimal dalam menjalankan proses pendidikannya, dorongan dan dukungan dari orang tua yang paling menonjol bagi seoarng pendidik yaitu status sosial ekonomi.

Status sosial ekonomi keluarga sangatlah penting untuk mendukung proses pendidikan, karena kebutuhan akan pendidikan tidaklah sedikit meskipun pemerintah sudah ikut berperan atau berpartisipasi dalam proses pendidikan seperti adanya bantuan bagi peserta didik namun semua itu tidaklah cukup untuk memenuhi semua kebutuhannya. Kebutuhan yang lain selain bantuan yang diberikan oleh pemerintah seperti kebutuhan akan perlengkapan alat tulis dan juga kebutuhan yang lain yang dibutuhkan untuk berjalannya proses pendidikan itu semua mestinya dikeluarkan oleh keluarga terutama orang tua, jadi tidak semuanya kebutuhan itu dikeluarkan oleh pemerintah.Status sosial ekonomi yang dimiliki seseorang tidaklah sama, setiap manusia otomatis memiliki status sosial yang berbeda, ada yang memiliki status sosial yang tinggi ada pula yang memiliki status sosial menengah bahkan ada yang rendah. Orang yang memiliki status sosial ekonomi tinnggi atau atas ini termasuk golongan orang yang mampu memenuhi kebutuhannya baik kebutuhan primer,skunder maupun tersiernya, mereka akan selalu memperhatikan bagaimana pola hidup dari anak-anaknya, baik pola makan maupun pola pergaulan serta pola pendidikannya.

Status sosial ekonomi, secara umum bisa dikatakan penggolongan status sosial keluarga 
yang berada dalam sebuah masyarakat yang ada kaitannya dengan kemampuan seseorang dalam memenuhi kebutuhan sehari-harinya yang bisa dilihat dari kemauan dan usahanya agar bisa mencapai kesejahteraan dalam hidupnya.Afiyati,(2014) menjelaskan bahwa Status sosial ekonomi merupakan gabungan antara status sosial dan kondisi ekonomi disebuah masyarakat.

Sedangkan kelompok dengan status sosial menengah termasuk kedalam golongan orang yang mampu memenuhi kebutuhannya namun golongan status sosial ini berbeda dengan golongan yang berstatus sosial tinggi atau atasdalam memenuhi kebutuhannya, kalau golongan yang berstatus sosial tinggi dalam memenuhi kebutuhannya tanpa harus memilih priyoritas dari kebutuhannya namun jika golongan yang berstatus sosial menengah dalam pemenuhan kebutuhannya masih harus memilih barang priyoritas yang dibutuhkan, artinya yaitu tidak semua barang yang di inginkan harus di beli.Selanjutnya adalah kelompok denagan status sosial ekonomi bawah atau rendah, kelompok dengan status sosial yang rendah ini berbeda dengan kelompok status sosial ekonomi atas dan menengah, kalau kelompok dengan status sosial ekonomi atas dan menengah biasanya mampu memenuhi kebutuhannya tetapi bagi kelompok dengan status sosial bawah atau rendah ini masih kekurangan dalam memenuhi kebutuhannya yang masih tergolong sederhana namun terkadang masih tidak dapat terpenuhi kebutuhannya. Biasanya kelompok dengan status sosial rendah ini adalah orang yang termasuk kalangan bawah seperti petani dan lain sebagainya.

Keadaan ekonomi dari orang tua siswa akan menjadi pendukung terhadap sarana dan prasarana dalam proses belajarnya, yang nantinya akan memudahkan terhadap pihak sekolah dalam proses belajar mengajar yang berlangsung di sebuah sekolah. Dalam proses belajar mengajar akan membutuhkan biaya yang tidak sedikit walaupun pemerintah sudah ikut berperan dalam hal ini namun semua itu masih belum cukup untuk memnuhi kebutuhan peralatan sekolah sepenuhnya. Peralatan sekolah yang dimaksud yaitu sperti: Buku pelajaran, pensil, penggaris, penghapus dan masih banyak peralatan lain yang dibutuhkan dalam proses belajar. Mungkin bagi mereka yang berstatus sosial tinggi dan mampu memenuhi kebutuhan sehari-harinya akan merasa gampang dalam memenuhi kebutuhan sekolah dari anaknya, namun bagi mereka yang status sosial ekonominya rendah mereka akan merasa kesulitan dalam mencukupi kebutuhan sekolah putra putrinya dan akan lebih berhati-hati dalam menjaga perlengkapan yang dimiliki oleh anaknya, Karena status sosial yang dimiliki orang tidaklah sama serta mempunyai cara yang berbeda dalam menyikapinya.Adapun indikator dari status sosial ekonomi orang tua yaitu: (1) pekerjaan, (2) pendapatan, (3) pendidikan dan (4) kepemilikan.

Berdasarkan hasil diskusi peneliti dengan kepala sekolah dan sebagian siswa di lokasi yang dijadikan tempat penelitian, status sosisal ekonomi keluarga dari siswanya bervariasi, ada yang berstatus tinggi, menengah dan rendah.Hal itu bisa dilihat dari pekerjaan orang tua siswa yaitu ada yang berprofesi sebagai Guru, wiraswasta, petani, nelayan, kuli bangunan, supir angkot dan juga pedagang.Manusia sebagai makhluk sosial pasti akan saling membutuhkan dan saling berhubungan sosial dengan manusia yang lainnya terutama dengan teman sebayanya. MenurutSantrock,(2007)Teman sebaya merupakn anak-anak atau remaja yang mempunyaii usia dan tingkat kematangan yang sama. Jadi jika seseorang memiliki tingkat usia yang sama serta kematangan yang sama maka mereka bisa dikatakan sebagai teman sebaya, bagi mereka yang berteman dengan teman sebayanya akan merasa lebih nyaman dalam hal komunikasinya, berbeda halnya dengan mereka yang berkumpul bersama dengan orang yang jauh berbeda usianya maka dia akan merasa kurang nyaman dalam masalah berkomunikasinya walaupun ada sebagian orang yang merasa nyaman dengan siapapun ia berkomunikasi.

Teman sebaya bisa memberikan dampak positif dan juga dampak negatif terhadap siswa (anak). Pola pikir dari teman sebayanya juga akan memebrikan pengaruh terhadap proses pembentukan sikapnya, ketika seorang anak mau bergabung dengan teman sebayanya namun ada penolakan dari temannya karena suatu perbedaan tingkah laku dan lain sebagainya, maka anak tersebut akan mengubah sikapnya dan lebih cenderung mengikuti tingkah laku dari temantemannya agar bisa diterima oleh teman sebayanya. Adapun indikator dari teman sebaya menurut David, (2012) yaitu: (1) Lebih dari satu orang, (2) Mempunyai tingkat usia dan kepribadian yang sama, (3) Ada interaksi antar 
anggota, (4) Saling ketergantungan satu sama lainnya, (5) Memiliki tujuan yang sama.Berdasarkan hasil diskusi peneliti dengan kepala sekolah di lokasi yang akan diteliti, siswa di sekolah MTs apabila masih berstatus siswa baru (baru masuk sekolah) di sekolah tersebut maka hanya berkumpul dengan para siswa yang berasal dari dusun yang sama, karena bagi anak desa belum berani untuk membaur dengan teman yang baru dikenalnya, tapi apabila sudah saling mengenal satu sama lain, mereka akan saling membaur dari manapun mereka berasal. Minat ialah kecenderungan atau kemauan yang besar terhadap sesuatu Syah, (2001).Ada dua faktor yang dapat mempengaruhi minat seseorang Syah, (2001), yaitu: 1) Faktor internal, yaitu dorongan dari dalam diri seseorang untuk melakukan sesuatu. 2) Faktor eksternal yaitu dorongan yang datangnya dari luar diri seseorang untuk melakukan sesuatu. Adapun indikator minat melanjutkan menurut (slameto, 2010) yaitu: 1) Perasaan senang, (2) Ketertarikan siswa, (3) Perhatian siswa, (4) kemauan.

Menurut slameto, (2010), Minat merupakan sebuah rasa suka dan rasa tertarik seseorang terhadap suatu hal atau aktivitas yang timbul dari dalam seseorang tanpa ada yang menyuruhnya. Adapun faktor yang dapat mempengaruhi minat seseorang salah satunya adalah status sosial ekonomi. Sedangkan yang dapat mempengaruhi status sosial ekonomi yaitu: pekerjaan, pendapatan, pendidikan, serta kepemilikan. Jika dalam suatu keluarga status ekonominya baik, maka ada kemungkinan hal itu akan berpengaruh positif terhadap minat untuk melanjutkan pendidikan. Seperti penelitian yang sudah pernah dilakukan sebelumnya oleh Fitriani, (2014) bahwa status sosial ekonomi keluarga berpengaruh positif terhadap minat melanjutkan.

Teman sebaya ialah anak-anak yang memiliki tingkat usia yang sama dan tingkat kematangan yang sama, teman seabaya juga merupakan teman yang cocok untuk diajak ngobrol dan bertukar pendapat Soetjiningsih, (2012). Teman sebaya sangatlah berperan penting dalam kehidupan manusia khususnya pada kalangan remaja dan anak-anak, karena dengan adanya teman sebaya bisa saling bertukar pendapat satu sama lain. Seperti halnya penelitian yang sudah pernah dilakukan oleh Wulandari, (2017) yaitu terdapat pengaruh positif dan signifikan terhadap minat melanjutkan pendidikan.
Untuk mengetahui pengaruh secara simultan antara status sosial ekonomi keluarga dan teman sebaya terhadap minat melanjutkan tingkat SLTA maka dilakukan uji F. Berdasarkaan hasil tes ANOVA ditemukan nilai $\mathrm{F}$ hitung sebesar 26,164 dengan tingkat signifikansinya sebesar 0.000 , karena tingkat signifikansinya kurang dari $0.05(<0.05)$ itu artinya hipotesis kedua ditolak dan hipotesis pertama diterima yaitu terdapat pengaruh secara simultan antara status sosial ekonomi dan teman sebaya terhadap minat melanjutkan tingkat SLTA di MTs se Kecamatan Kwanyar

Berdasarkan latar latar belakang yang ditulis peneliti maka serta rumusan masalah yang disusun peneliti maka tujuan dari penelitian ini yaitu: 1) menganalisis pengaruh secara parsial antara status sosial ekonomi keluarga terhadap minat melanjutkan tingkat SLTA, 2) menganalisis pengaruh secara parsial antara teman sebaya terhadap minat melanjutkan tingkat SLTA, 3) menganalisis pengaruh secara simultan antara status sosial ekonomi keluarga dan teman sebaya terhadap minat melanjutkan tingkat SLTA.

\section{METODE PENELITIAN}

Adapun jenis penelitian yang digunakan yaitu penelitian kuantitatif dengan pendekatan asosiatif kausal karena terdiri dari dua variabel bebas dan satu variabel terikat. Rancangan penelitian yang dilakukan menggunakan paradigma ganda. Adapun lokasi yang dijadikan sebagai tempat penelitian yaitu di MTs se Kecamatan Kwanyar.Sedangkan waktu pelaksanaannya yaitu pada tahun 2018. Adapun populasi yang diambil dalam penelitian ini adalah siswa kelas IX MTs se Kecamatan Kwanyar, yang mana di kecamatan tersebut terdapat tiga sekolah MTs yaitu: (1) MTs Manba'ul Ulum (2) MTs Raudatul Ulum (3) MTs Sunan Cendana.

Adapun jumlah populasi dalam penelitian ini sebanyak 113 siswa. Simple random sampling digunakan peneliti untuk mengumpulkan data penelitian yaitu anggota sampel yang diambil dari populasi dilakukan dengan cara acak yaitu tidak harus memperhatikan strata yang termasuk kedalam populasi dari MTS se Kecamatan Kwanyar. Instrumen penelitian yang digunakan yaitu menggunakan skala likert 1-4, Instrumen yang digunakan berupa angket dengan menguji butir 
soal melalui uji validitas dan reliabilitas. Untuk variabel X1 yang terdiri dari 7 butir soal semuanya valid hal itu diketahui dari nilai $r$ hitung yang lebih besar dengan nilai $r$ terkoreksinya, begitu juga hasil reliabilitasnya semuanya reliabel hal itu diketahui dari nilai koefisien alphanya lebih dari $60 \% \quad(0,6)$, selanjutnya untuk variabel X2 yang terdiri dari 9 butir soal semuanya valid dan reliabel, hal itu juga dilihat dari nilai $r$ hitung dan koefisien alphanya serta hasil uji validitas variabel $\mathrm{Y}$ yang terdiri dari 10 butir soal semuanya valid dan reliabel hal itu diketahui dari hasil $r$ hitung dan koefisien alphanya. Teknik pengumpulan data melalui metode interview, kuesioner serta dokumentasi. teknik analisis data ini melalui model analisis regresi linier berganda diantaranya uji asumsi klasik dengan melakukan Uji normalitas, Uji Multikolinieritas, Uji heteroskedastisitas, Uji Linieritas, dan Uji Hipotesis dengan melalui uji F dan uji T, serta uji koefisien determinasi.

\section{HASIL DAN PEMBAHASAN}

Setelah dilakukan analisis regresi linier berganda maka peneliti dapat mengetahui besar konstanta dan koefsien regresi dari masingmasing variabel yaitu Nilai konstanta menunjukkan sebesar 23,858 menunjukan pengaruh positif variabel bebas. Nilai koefisien regresi variabel status sosial ekonomi keluarga terhadap minat melanjutkan (Y) sejumlah 0,863 artinya jika variabel status sosial ekonomi keluarga mengalami kenaikan satu satuan, maka variabel minat melanjutkan (Y) akan menglami peningkatan sebesar 0,863 atau $8,63 \%$. Adapun hasil persamaannya yaitu:

$\mathrm{Y}=23,538+0,614 \mathrm{X} 1-0,399 \mathrm{X} 2$

Minat melanjutkan tingkat SLTA $=23,538+$ 0,614 (status sosial ekonomi) -0,399 (teman sebaya).

Nilai koefisien regresi variabel teman sebaya (x2) terhadap minat melanjutkan (y) sebesar -0,320 maksudnya, jika variabel teman sebaya mengalami kenaikan satu satuan, jadi variabel minat melanjutkan (y) akan menglami penurunan sebesar $-0,320$ atau $-3,20 \%$. Koefisien bernilai negatif artinya menunjukan bahwa antara variabel teman sebaya dan minat melanjutkan berhubungan negatif. Kenaikan teman sebaya (x2) akan mengakibatkan kenaikan minat melanjutkan $(\mathrm{y})$.
Koefisien determinasi (R2) adalah besarnya kontribusi variabel status sosial ekonomi keluarga (x1) dan teman sebaya (x2) terhadap variabel minat melanjutkan tingkat SLTA (y), $\mathrm{R}$ di regresi linier berganda bahwasanya nilai korelasi berganda: Angka $\mathrm{R}$ yang didapat adalah 0,617, dengan ini korelasi antara variabel status sosial ekonomi keluarga dan teman sebaya sebesar $6,17 \%$. Hal ini menunjukkan terjadi hubungan sangat kuat karena nilai mendekati 1 . R Square $\left(R^{2}\right) R$ menunjukkan Nilai $\mathrm{R}^{2}$ sebesar 0,381 maksudnya mengetahui seberapa persentase yang berkontibusi variabel status sosial ekonomi dan teman sebaya sebesar $38,1 \%$, sedangkan selebihnya dipengaruhi oleh variabel lain yang tidak dimasukkan dalam model ini sebesar 61,9\%. Adjusted R Square :nilainya sebesar 0,366 ini juga memperlihatkan sumbangan pengaruh variabel independen.

Pengujian Hipotesis pada uji $\mathrm{T}$ : nilai thitung pada variabel X1 (Status Sosial Ekonomi Keluarga) sebesar 6.825 dengan tingkat signifikasi sebesar 0.000 karena tingkat signifikansinya < dari 005 jadi variabel X1 (Status Sosial Ekonomi Keluarga) berpengaruh signifikan dengan variabel Y (Minat Melanjutkan) jadi Ha1 diterima dan Ho1 ditolak. Uji F menunjukkan Dari hasil tes Anova ditemukan nilai F-hitungnya sebesar 26,164 dengan tingkat signifikan 0.000 dikarenakan tingkat signifikan lebih besar dari 0.05, maka Ha3 diterima dan Ho3 ditolak yaitu: Ada pengaruh secara simultan antara status sosial ekonomi keluarga dan teman sebaya terhadap minat melanjutkan tingkat SLTA di MTs se kecamatan kwanyar.

Uji Asumsi Klasik menunjukkan melalui uji normalitas nilai signifikasi Asymp.sig.(2tailed) sebesar 0,200 Karena signifikasi lebih besar dari 0,05 $(0,200>0,05)$ oleh karena itu nilai residual $\mathrm{t}$ normal. Dengan demikian, bisadisimpulkan bahwa regresi memenuhi persyaratan normalitas. Uji Multikolinieritas menunjukkan nilai tolerance dari kedua variabel itu lebih dari 0,1 dan nilai VIF lebih dari 10 oleh itu, bisa diatrik sebuah kesimpulan tidak terjadi masalah multikolinieritas dalam model ini. Uji Heteroskedastisitas menunjukkan hasil Dari hasil output gambar scatterplot diatas bisa kita lihat bahwa titik-titiknya tidak beraturan. Titik-titiknya menyebar diatas dan dibawah angka 0 pada sumbu Y. Sehingga hasilnya adalah bahwasanya 
tidak ada masalah heteroskedastisitas pada pola regresi ini. Uji Autokorelasi: nilai Durbin Watson sejumlah 2,103. Karena nilai DW terletak antara DL < DW < 4-DU $(1,612<2,103<2,27)$ maka hasilnya tidak terjadi autokorelasi. Uji Linieritas: bahwa nilai signifikansi sebesar 0,301. Karena nilai signifikansinya lebih besar dari 0,05 maka bisa kita simpulkan terdapat hubungan secara linear antara variabel bebas $(\mathrm{X})$ dengan variabel terikat (Y).

\section{HASIL DAN PEMBAHASAN}

Pengaruh Status Sosial Ekonomi Keluarga Terhadap Minat Melanjutkan Tingkat SLTA di MTs se Kecamatan Kwanyar

Dari hasil penelitian yang dialkukan peneliti dapat diketahui bahwasanya status sosial ekonomi keluarga (X1) berpengaruh positif dan signifikan terhadap minat melanjutkan tingkat SLTA (Y). Hal tersebut dapat dibuktikan dari nilai coefisien regresi sebesar 0,863 pada taraf signifikansinya sebesar $0,000<0,05$ karena tingkat signifikannya $<0,05$ maka kesimpulannya adalah terdapat pengaruh positif dan signifikan antara X1 terhadap Y. Hal tersebut menunjukkan bahwa status sosial ekonomi memberikan kontribusi terhadap minat melanjutkan tingkat SLTA di MTs se Kecamatan Kwanyar. Hal yang menyebabkan status sosial ekonomi keluarga berpengaruh positif dan signifikan terhadap minat melanjutkan tingkat SLTA yaitu karena status sosial ekonomi keluarga yang dimiliki siswa MTs di Kecamatan Kwanyar sudah mendukung untuk mereka melanjutkan pendidikan yang lebih bagus.

Hasil penelitian ini mirip penelitian yang dilakukan oleh (Latifah, 2015)bahwa Status sosial ekonomi orang tua berpengaruh secara signifikan terhadap minat melanjutkan pendidikan ke perguruan tinggi sebesar 16,81\%. Sedangkan pada penelitian yang dilakukan (Fitriani, 2014) juga memaparkan bahwa Status sosial ekonomi orang tua juga memiliki pengaruh positif terhadap minat melanjutkan pendidikan sebesar $21,53 \%$. Hasil penelitian mirip dengan penelitian yang sudah dilakukan sebelumnya oleh Suciningrum \& Rahayu, (2017)yaitu Status sosial ekonomi keluarga berpengaruh langsung terhadap minat melanjutkan ke perguruan tinggi sebesar 0.22 atau $22 \%$.Hasil pada penelitian ini beda halnya dengan penelitian yang dikerjakan oleh fatimah, (2018)bahwa status sosial ekonomi tidak berpengaruh secara signifikan terhadap minat melanjutkan pendidikan ke fakultas ekonomi di perguruan tinggi sebesar 0.21 dan pvalue 0-04. Penelitian ini juga tidak mirip hasilnya oleh penelitian yang dikerjakan oleh Darmawan, (2017) yaitu tidak ada pengaruh positif dan signifikan status sosial ekonomi orang tua terhadap minat melanjutkan pendiikan ke perguruan tinggi pada siswa SMA Negeri 1 Bayat.

Keadaan ekonomi dari orang tua sebenarnya sangat berpengaruh terhadap keinginan seorang anak agar bisa melanjutkan pendidikan yang ia inginkan. Hal ini sejalan dengan pendapat Nasution, (2004)bahwa pendidikan membutuhkan uang yang meliputi buku, pakian dll Di MTs se Kecamatan Kwanyar, status sosial ekonomi dari keluarganya beragam, Hal itu dilihat dari pekerjaan atau profesi yang dimiliki orang tuanya. Dari total semua siswa hanya sebagian saja yang memliki ekonomi yang tinggi, tinggi rendahnya ekonomi yang dimiliki Orang Tua, itu akan mempengaruhi pada minat anak untuk melanjutkan pendidikan. Terkadang meskipun Orang tua memiliki ekonomi yang cuckup, jika dorongan dari dalam diri anaknya itu kurang,maka itu tidak akan meningkatkan keinginan anak untuk bisa melanjutkan pendidikan yang ia inginkan. Jadi kesimpulannya bukan hanya faktor ekonomi saja yang dapat mempengaruhi minat seseorang untuk melanjutkan pendidikan, namun faktor internal juga akan mempengaruhi minat.

Pengaruh Teman Sebaya Terhadap Minat Melanjutkan Tingkat SLTA di MTs se Kecamatan Kwanyar

Sesuai dengan penelitian yang dilakukan peneliti, menjelaskan bahwasanya teman sebaya (X2) berpengaruh negatif dan signifikan terhadap minat melanjutkan tingkat SLTA (Y).oleh krena itu bisa dibuktikan dari nilai koefisien regresi sejumlah -0,320 dengan tingkat signifikansinya sebesar 0,000, dikarenakan nilai signifikansinya $<$ 0,05 maka kesimpulannya variabel X2 (Teman Sebaya) berpengaruh negatif terhadap minat melanjutkan tingkat SLTA di MTs se Kecamatan Kwanyar.

Hasil dari penelitian ini berbeda hasilnya dengan penelitian sebelumnya yang dilakukan oleh budiarti, (2015)bahwasanya teman sebaya berpengaruh positif dan signifikan terhadap minat melanjutkan ke perguruan tinggi padaSiswa kelas 
XII Jurusan Administrasi Perkantoran di SMKN 2 Semarang sebesar16,97\%. Hasil penelitian ini berbeda dengan penelitian yang dilakukan oleh penelitian sebelumnya yang sudah dilakukan oleh Darmawan, (2017)bahwa teman sebaya berpengaruh positif dan signifikan terhadap minat melanjutkan ke perguruan tinggi pada Siswa di SMAN 1 Bayat sebesar 7,95\%. Teman sebaya sangat mempengaruhi anak untuk bisa meneruskan pendidikan yang lebih tinggi, karena pada umumnya pelajar di sekolah khususnya yang masih berada di bangku MTs/Sederajat mereka masih sangat bergantung pada temantemannya, karena bagi mereka teman adalah seseorang yang bisa dijadikan tempat curahan maslah di sekolahnya. Hal tersebut berkaitan dengan hasil penelitian bahwa teman sebaya berpengaruh negative karena pada umumnya siswa /siswi yang lulus dari sekolah tersebut tidak banyak yang melanjutkan melainkan banyak yang bekerja atau nganggur dirumah membantu orang tuanya.

Pengaruh Status Sosial Ekonomi Keluarga dan Teman Sebaya Terhadap Minat Melanjutkan Tingkat SLTA di MTs se Kecamatan Kwanyar.

Dari hasil penelitian yang dilakukan peneliti menjelaskan bahwasanya status sosial ekonomi keluarga dan teman sebaya berpengaruh positif dan signifikan terhadap minat melanjutkan tingkat SLTA di MTs se kecamatan Kwanyar. Hal tersebut dapat dibuktikan dengan uji $F$ (uji simultan) dengan nilai $F$ hitung yang diperoleh sebesar 26,164 dengan tingkat signifikansi 0,000, karena nilai signifikan kurang dari $0,05(\mathrm{p}<0,05)$ maka dapat dikatakan terdapat pengaruh secara simultan antara status sosial ekonomi keluarga dan teman sebaya terhadap minat melanjutkan tingkat SLTA di MTs se Kecamatan Kwanyar.

Hasil penelitian ini sama dengan hasil penelitian yang dikerjakan oleh Latifah, (2015) dengan judul pengaruh motivasi, prestasi belajar, status sosial ekonomi orang tua dan lingkungan teman sebaya terhadap minat melanjutkan perguruan tinggi pada siswa kelas XII kompetensi keahlian akutansi si SMK Negeri se kota semarang tahun ajaran 2014/2015. Jadi selain faktor-faktor yang telah dijelaskan diatas yang dapat mempengaruhi minat siswa untuk melanjutkan adalah faktor status sosial ekonomi keluarga dan jaga teman sebaya. Sehingga dari hasil penelitian yang dilakukan diatas dan penelitian yang terdahulu bisa diambil kesimpulannya bahwasanya semakin tinngi status ekonomi keluarga maka akan semakin tinggi pula keinginan seseorang agar bisa melanjutkan pendidikan, serta semakin banyak pergaulan dengan teman sebaya maka akan semakin antusias seorang siswa untuk sekolah ke tingkat yang lebih tinggi.

\section{KESIMPULAN}

Berdasarkan hasil yang diperoleh dari penelitian bisa disimpulkan bahwa: 1) Status sosial ekonomi keluarga berpengaruh secara signifikan terhadap minat melanjutkan tingkat SLTA di MTs se Kecamatan Kwanyar. 2) Teman sebaya berpengaruh negatif signifikan terhadap minat melanjutkan tingkat SLTA di MTs se kecamatan Kwanyar. 3) Status sosial ekonomi keluarga dan teman sebaya berpengaruh secara signifikan terhadap minat melanjutkan tingkat SLTA di MTs se Kecamatan Kwanyar.

\section{SARAN}

Berdasarkan penelitian yang dilaksanakan oleh peneliti ada beberapa saran yang harus peneliti berikan, yaitu: 1) Orang tua diharapkan memperhatikan pendidikan anaknya khususnya fasilitas yang seharusnya diterima oleh anak-anaknya terutama kelengkapan srana dan prasarana untuk anak agar aank lebih semangat dan lebih focus pada sekolahnya. 2) Bagi siswa disetiap sekolah pergaulan dengan teman sangatlah baik, namun harus dibatasi juga jangan sampai melampaui batas pertemanan. Manfaatkanlah teman-teman kalian untuk hal-hal yang dapat meningkatkan prestasi dan hal yang berguna untuk kepentingan sekolah kalian. 3) perhatikanlah terlebih dahulu isi dari penelitian ini sebelum menjadikan bahan acuan untuk penelitian selanjutnya, dan carilah variabel yang ada teorinya dalam pembuatan skripsi jangan sekali-kali membuat teori sendiri.

\section{DAFTAR PUSTAKA}

Afiyati, B. (2014). Pengaruh status sosial ekonomi orang tua dan konsumsi siswa kelas XI IPS MAN Sidoarjo. Jupe, 2(3), 1-17.

Andrienzens. (2008). pengaruh pendidikan formal,non formal,informal terhadap prestasi pendidikan. jakarta: yudhistira.

budiarti, dhian septi. (2015). Pengaruh 
Lingkungan Teman Sebaya, Kondisi Sosial Ekonomi Orang Tua, dan Peran Guru Terhadap Minat Melajutkan Studi Ke Perguruan Tinggi (Studi Kasus Siswa Kelas XII Jurusan Administrasi Perkantoran di SMK Negeri 2 Semarang Tahun Ajaran 2014/2015".

Darmawan, I. (2017). Pengaruh Status Sosial Ekonomi Dan Lingkungan Teman Sebaya Terhadap Minat Melanjutkan Studi $\mathrm{Ke}$ Perguruan Tinggi Pada Siswa, (3), 156-165.

david, G. M. (2012). psikologi sosial jilid 2 . jakarta: Salemba Humanika.

fatimah, siti. (2018). Pengaruh potensi diri,prestasi belajar,status sosial ekonomi orang tua terhadap minat melanjutkan pendidikan ke fakultas ekonomi di perguruan tinggi, 6(2), 28-36.

Fitriani, K. (2014). Pengaruh Motivasi,Prestasi Belajar,Status Sosial Ekonomi Orang Tua Dan Lingkungan Sekolah Terhadap Minat Melanjutkan Ke Perguruan Tinggi Pada Siswa Kelas XII Akuntansi SMK Negeri 1 Kendal. Economic Education Analysis Journal, 2(1), 18-23.

ihsan, fuad. (2008). dasar dasar kependidikan. jakarta: Rineka Cipta.

Latifah, N. K. dan L. (2015). Pengaruh Motivasi, Prestasi Belajar, Status Sosial Ekonomi Orang Tua dan Lingkungan Teman Sebaya Terhadap Minat Melanjutkan pendidikan ke Perguruan Tinggi pa Siswa Kelas 12 Kompetensi Keahliah Akunansi di SMK Negri se Kota Semarang Tahun Ajaran 2014/2015. Economic Education Analysis Journal, 4(3), 833-846. https://doi.org/ISSN 2252-6544

Nasution. (2004). Sosiologi pendidikan. Bandung: Jammars.

Santrock, J. W. (2007). Remaja. ( novietha indra sallama, Ed.) (11th ed.). jakarta: Erlangga.

slameto. (2010). Belajar dan Faktor-Faktor yang mempengaruhinya. jakarta: Rineka Cipta. https://doi.org/2003

Soetjiningsih, C. H. (2012). Perkembangan anak (Vol. 2). jakarta.

Suciningrum, N. P., \& Rahayu, E. S. (2017). Pengaruh Status Sosial Ekonomi Orang Tua Dan Motivasi Belajar Tehadap Minat Melanjutkan Studi Ke Perguruan Tinggi Pada Kelas Xi Di Sma Pusaka 1 Jakarta. Jurnal Pendidikan Ekonomi Dan Bisnis (JPEB), 3(1), 1. https://doi.org/10.21009/jpeb.003.1.1

Syah, M. (2001). Psikologi pendidikan. jakarta: Bumi Aksara.
Wulandari, R. (2017). Pengaruh Status Sosial Ekonomi Orang Tua Terhadap Motivasi Belajar Siswa Di Madrasah Aliyah Pondok Pesantren Al-Hamidiyah. 